\title{
An Improved Protocol for Asymbiotic Seed Germination and Seedling Development of Paphiopedilum tigrinum
}

\author{
Linling Yao ${ }^{1,2}$, Jialin Huang ${ }^{3, *}$ and Shibao Zhang ${ }^{1, *}$ \\ 1 Key Laboratory of Economic Plants and Biotechnology, Kunming Institute of Botany, \\ Chinese Academy of Sciences, Kunming 650201, China; yaolinling@mail.kib.ac.cn \\ 2 Academy of Life Science, University of Chinese Academy of Sciences, Beijing 100049, China \\ 3 School of Chemical Biology and Environment, Yuxi Normal University, Yuxi 653100, China \\ * Correspondence: hjl@yxnu.edu.cn (J.H.); sbzhang@mail.kib.ac.cn (S.Z.)
}

Citation: Yao, L.; Huang, J.; Zhang, S An Improved Protocol for Asymbiotic Seed Germination and Seedling Development of Paphiopedilum tigrinum. Horticulturae 2021, 7, 298. https://doi.org/10.3390/ horticulturae7090298

Academic Editors: Fure-Chyi Chen and Jian-Zhi Huang

Received: 28 July 2021

Accepted: 3 September 2021

Published: 9 September 2021

Publisher's Note: MDPI stays neutral with regard to jurisdictional claims in published maps and institutional affiliations.

Copyright: (c) 2021 by the authors. Licensee MDPI, Basel, Switzerland. This article is an open access article distributed under the terms and conditions of the Creative Commons Attribution (CC BY) license (https:// creativecommons.org/licenses/by/ $4.0 /)$.

\begin{abstract}
Paphiopedilum tigrinum is an endangered orchid with high ornamental value. However, seed germination and seedling regeneration in P. tigrinum is very difficult in vitro. Little is known about why $P$. tigrinum seedlings are difficult to propagate or how to improve the seed germination and seedling rates of this species. In this study, we investigated the developmental process of $P$. tigrinum from asymbiotic seed germination to seedling rooting by comparing it with P. appletoniantum, a much easier species for germination and seedling formation. We found that asymbiotic seed germination in P. tigrinum is limited by severe browning of the protocorm at the seed germination stage, and protocorm rooting at the differentiation stage was also proved to be difficult. The optimal medium for seed germination of P. tigrinum was a modified Harvais (mHa) medium supplemented with $0.5 \mathrm{mg} \cdot \mathrm{L}^{-1}$ kinetin (Kin), $0.1 \mathrm{~g} \cdot \mathrm{L}^{-1}$ activated charcoal (AC) and $100 \mathrm{~mL} \cdot \mathrm{L}^{-1}$ coconut water (CW). At the protocorm differentiation stage, seedlings with 1-2 leaves were obtained on a 1/4 MS medium supplemented with $1.0 \mathrm{mg} \cdot \mathrm{L}^{-1}$ 6-benzylaminopurin (BA), $0.3 \mathrm{~g} \cdot \mathrm{L}^{-1} \mathrm{AC}$ and $50-100 \mathrm{~mL} \cdot \mathrm{L}^{-1} \mathrm{CW}$ after culturing for 120 day. At the seedling subculture stage, a 1/2 MS medium supplemented with 0.5-1.5 $\mathrm{g} \cdot \mathrm{L}^{-1} \mathrm{AC}$ and $100 \mathrm{~mL} \cdot \mathrm{L}^{-1} \mathrm{CW}$ was better for leaf and root growth of P. tigrinum. At the rooting stage, a $1 / 2$ MS medium supplemented with $1.0 \mathrm{~g} \cdot \mathrm{L}^{-1} \mathrm{AC}, 0.5 \mathrm{~g} \cdot \mathrm{L}^{-1}$ dolomite flour, $15 \mathrm{~g} \cdot \mathrm{L}^{-1}$ potato homogenate and $30 \mathrm{~g} \cdot \mathrm{L}^{-1}$ banana homogenate was most suitable for the growth and rooting of seedlings. This study has established an effective protocol for seed germination and seedling regeneration of $P$. tigrinum.
\end{abstract}

Keywords: basal media; endangered orchid; germplasm conservation and utilization; in vitro propagation

\section{Introduction}

Members of the genus Paphiopedilum, commonly referred to as slipper orchids, are world-famous potted flowers. Species and hybrids in this genus are very popular in floriculture because of their attractive colors, large flowers and peculiar shapes and have been extensively cultivated and produce a wide range of attractive varieties, cultivars or hybrids as a result of intensive breeding [1-3].

Paphiopedilum tigrinum is a very endangered orchid. It usually grows on trees or mossy rocks or rocky places in open forests at elevations between 1200 and $2200 \mathrm{~m}$, and it flowers from May to August in the wild (Figure 1a) [4]. Natural populations of P. tigrinum have been drastically reduced in recent decades due to overcollection and habitat loss [5]. Consequently, P. tigrinum has been listed in Appendix I of the Convention on International Trade in Endangered Species of Wild Fauna and Flora [6] and is under special protection. At present, regenerating Paphiopedilum plantlets through the division of axillary buds from the mother plant is time-consuming and inefficient [7]. Although there have been rapid developments in tissue culture over the last century, progress on tissue culture of Paphiopedilum is currently sporadic and unsuitable for commercial applications [7-10]. 
Thus, large-scale propagation of Paphiopedilum is mainly achieved by asymbiotic seed germination [11].
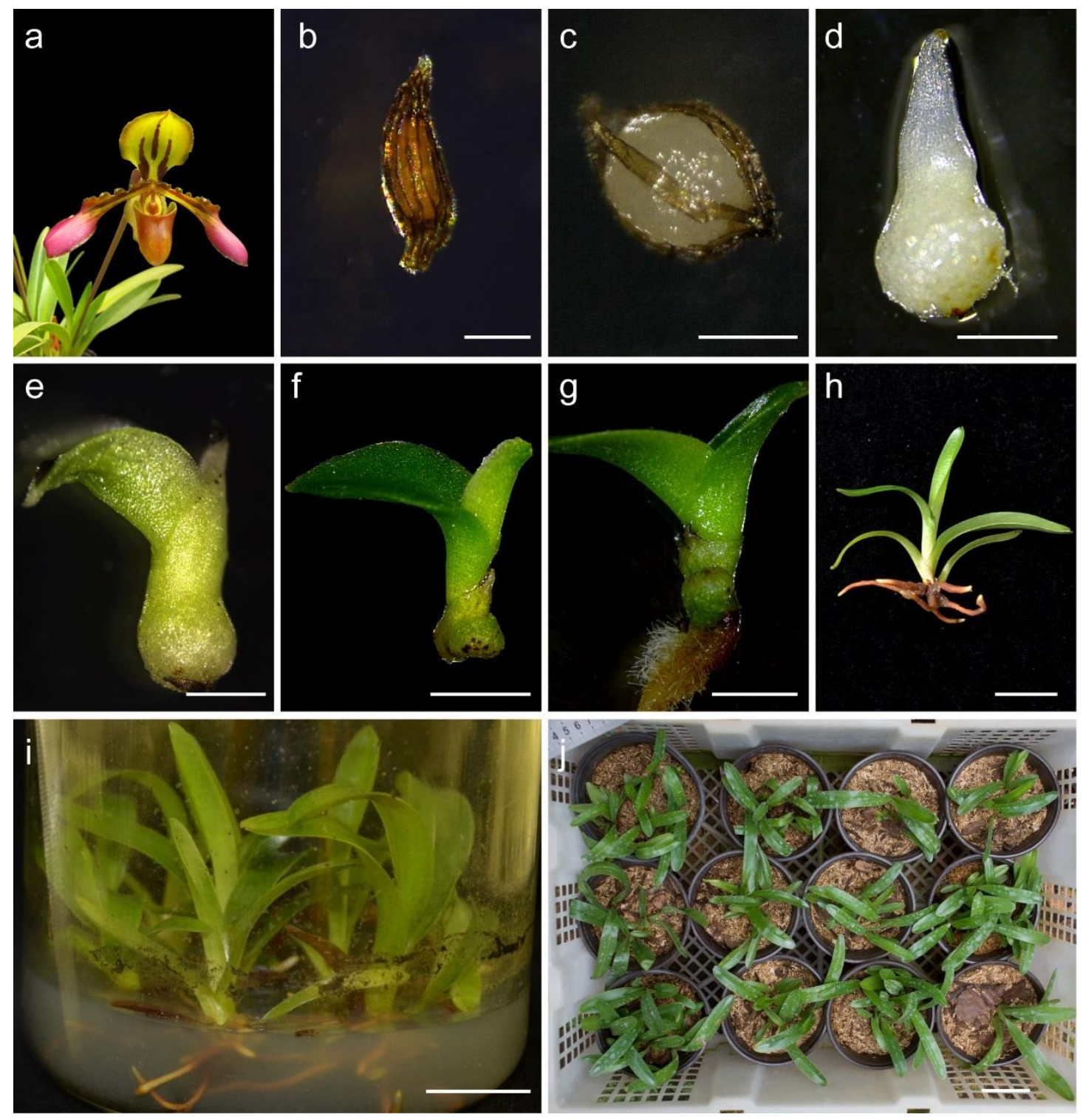

Figure 1. In vitro seed germination of Paphiopedilum tigrinum. (a) Flowering plants of P. tigrinum; (b) a mature seed with dark brown and opaque seed coat; (c) testa ruptured; (d) appearance of the shoot and rhizoids; (e) emergence and elongation of the first leaf; $(\mathbf{f}, \mathbf{g})$ presence of the second leaf and roots; $(\mathbf{h}, \mathbf{i})$ seedlings with green leaves and roots cultured on the $1 / 2 \mathrm{MS}$ medium containing $0.5 \mathrm{~g} \cdot \mathrm{L}^{-1}$ dolomite flour, $1.0 \mathrm{~g} \cdot \mathrm{L}^{-1}$ activated charcoal, $15 \mathrm{~g} \cdot \mathrm{L}^{-1}$ potato homogenate and $30 \mathrm{~g} \cdot \mathrm{L}^{-1} \mathrm{banana}$ homogenate for 6 months; (j) seedlings maintained in the greenhouse for three months. Bar: (b,c) $500 \mu \mathrm{m} ;(\mathbf{d}-\mathbf{g}) 2 \mathrm{~mm}$; (h-j) $4 \mathrm{~cm}$.

The seeds of Paphiopedilum species are considered difficult to germinate and regenerate in vitro because they lack endosperm $[3,12,13]$. Since Knudson [14] germinated orchid seeds asymbiotically, much effort has been made to optimize this technique [15-17]. Seed germination and seedling development have been found to be affected by internal and external factors, including seed maturity, seed pretreatment, cultivation method, cultivation conditions, media composition and other unknown factors [12,18]. Much success has been achieved with asymbiotic regeneration of Paphiopedilum species $[15-17,19,20]$. Species that were previously thought to have difficulty in germinating and forming seedlings can now germinate and grow well. For example, seed germination rate of P. spicerianum was significantly promoted from below $1 \%$ to $25 \%$ after pretreatment with $1 \% \mathrm{NaClO}$ for $40 \mathrm{~min}$, 
and seeds should be germinated in a $24 \mathrm{~h}$ dark photoperiod for approximately 30 days in $1 / 4$ MS media [16]. Seed germination of $P$. wardii was significantly improved by adjusting the media components, sodium hypochlorite treatment time and dark culture time [15]. Despite these successes, protocols for this technique must be developed species-by-species due to differences in physio-ecological characteristics and nutrient requirements [21]. Until now, the technology for asymbiotic seed germination of $P$. tigrinum has not been effectively developed. Two previous studies reported that the seed germination rate of this species is less than $1 \%$, and no seedlings are obtained $[22,23]$.

The purpose of our study was to identify the current difficulties in asymbiotic propagation of $P$. tigrinum and to establish an effective protocol for $P$. tigrinum seed propagation. For this purpose, we compared the development of P. tigrinum and P. appletoniantum (a species that germinates readily) at seed germination and protocorm differentiation and during the subculture of seedlings. In addition, we established an effective protocol for $P$. tigrinum seed propagation by optimizing culture conditions and the components of basal media. An effective method of seed propagation in vitro will aid in the conservation and commercial production of this endangered orchid species.

\section{Materials and Methods}

\subsection{Capsule Collection and Sterilization}

Healthy $P$. tigrinum and $P$. appletoniantum plants were grown in a greenhouse at the Kunming Institute of Botany, Yunnan, China. Mature seed capsules were collected at about 400 days after artificial pollination. The indehiscent capsules were washed three times with soapy water, sterilized by dipping into $0.1 \%$ mercuric chloride $\left(\mathrm{HgCl}_{2}\right)$ for $10-15 \mathrm{~min}$ and $75 \%(v / v)$ ethanol for $30 \mathrm{~s}$ and then flame-sterilized. After that, the capsules were cut open vertically, and mature seeds with a dark brown and opaque seed coat (Figure 1b) were sown on different media.

\subsection{Effect of Basal Media, Activated Charcoal, Plant Growth Regulators and Dark Culture on Asymbiotic Seed Germination}

To determine the effect of basal media, activated charcoal (AC), plant growth regulators (PGRs) and light on seed germination of P. tigrinum and P. appletoniantum, we designed four sets of experiments. (1) Three basal media were tested: 1/2 MS (Murashige and Skoog, 1962; 1/2 MS macro- and micronutrients); 1/4 MS; and modified Harvais (mHa) [24,25], supplemented with $1.0 \mathrm{mg} \cdot \mathrm{L}^{-1}$ kinetin (Kin), $100 \mathrm{~mL} \cdot \mathrm{L}^{-1} \mathrm{CW}$ and $0.5 \mathrm{~g} \cdot \mathrm{L}^{-1} \mathrm{AC}$ (iodine adsorption value of activated carbon was over $400 \mathrm{mg} \cdot \mathrm{g}^{-1}$, Tianjin Kemiou Chemical Reagent Co., Ltd., Tianjin China). (2) Seeds were cultured on mHa medium supplemented with $1.0 \mathrm{mg} \cdot \mathrm{L}^{-1} \mathrm{Kin} ; 100 \mathrm{~mL} \cdot \mathrm{L}^{-1} \mathrm{CW}$; and AC at $0.1,0.5,1.0$ and $2.0 \mathrm{~g} \cdot \mathrm{L}^{-1}$. (3) Seeds were sown on mHa medium supplemented with $100 \mathrm{~mL} \cdot \mathrm{L}^{-1} \mathrm{CW}$ and $\alpha$-naphthaleneacetic acid (NAA) or 6-benzylaminopurine (BA) or Kin at $0.5,1.0$ and $2.0 \mathrm{mg} \cdot \mathrm{L}^{-1}$. (4) Seeds were cultured in the dark on mHa media consisting of $1.0 \mathrm{mg} \cdot \mathrm{L}^{-1} \mathrm{Kin}, 100 \mathrm{~mL} \cdot \mathrm{L}^{-1} \mathrm{CW}$ and $0.5 \mathrm{~g} \cdot \mathrm{L}^{-1} \mathrm{AC}$ for $0,30,60$ and 90 days, before being transferred to a $12 \mathrm{~h}$ photoperiod.

All media were supplemented with $6 \mathrm{~g} \cdot \mathrm{L}^{-1}$ agar and $20 \mathrm{~g} \cdot \mathrm{L}^{-1}$ sucrose (Xilong Scientific Co., Ltd., Guangzhou, China) and had pH adjusted to 5.8 with $1 \mathrm{~N} \mathrm{NaOH}$ or $1 \mathrm{~N}$ $\mathrm{HCl}$ before being autoclaved at $121^{\circ} \mathrm{C}$ at a pressure of $1.05 \mathrm{~kg} \cdot \mathrm{cm}^{-2}$ for $15 \mathrm{~min}$. All plant growth regulators and agar were purchased from Chembase Co., Ltd., Beijing, China. All experiments consisted of 3-5 independent replicates with about 100 seeds per replicate. The seeds were placed in the dark during the germination period at $25 \pm 2{ }^{\circ} \mathrm{C}$. Cultures were observed every other week until the germination rate was stable. Germination was considered to have occurred only if a swollen embryo was present and the testa was ruptured $[15,26]$. The morphological characteristics and developmental progress of seeds and protocorms were observed using an Olympus SZ51 microscope (Olympus Corporation, Tokyo, Japan).

Total germination rate was calculated by the number of germinated seeds (including browned seeds) divided by the total number of cultured seeds in each flask. The browning 
rate was calculated by the number of vitrified and browned protocorms divided by the number of protocorms formed. The effective germination rate was calculated by the number of healthy protocorms divided by the total number of cultured seeds in each flask.

\subsection{Effect of Basal Media, Activated Charcoal and Plant Growth Regulators on Protocorm Differentiation}

One week after maximum germination, we assessed the effect of basal media, AC and PGRs on protocorm differentiation by transferring seed-derived protocorms to the following media: (1) 1/4 MS, 1/2 MS and MS media supplemented with $100 \mathrm{~mL} \cdot \mathrm{L}^{-1} \mathrm{CW}$ and $1.0 \mathrm{mg} \cdot \mathrm{L}^{-1} \mathrm{Kin}$; (2) a $1 / 4 \mathrm{MS}$ medium containing $100 \mathrm{~mL} \cdot \mathrm{L}^{-1} \mathrm{CW}, 1.0 \mathrm{mg} \cdot \mathrm{L}^{-1} \mathrm{Kin}$ and $\mathrm{AC}$ at $0.3,0.5$ and $1.0 \mathrm{~g} \cdot \mathrm{L}^{-1} ;(3)$ and a $1 / 4 \mathrm{MS}$ medium containing $100 \mathrm{~mL} \cdot \mathrm{L}^{-1} \mathrm{CW}$ and BA at $0.5,1.0$ and $2.0 \mathrm{mg} \cdot \mathrm{L}^{-1}$ in combination with NAA at $0.1,0.2$ and $0.5 \mathrm{mg} \cdot \mathrm{L}^{-1}$. Each treatment consisted of 3-5 independent replicates with 30 protocorms per replicate. The number of seedlings formed was recorded after 120 days of culture. The cultures were incubated at $25 \pm 2{ }^{\circ} \mathrm{C}$ and a $12 \mathrm{~h}$ photoperiod at $32-40 \mu \mathrm{mol} \cdot \mathrm{m}^{-2} \cdot \mathrm{s}^{-1}$.

\subsection{Effect of Activated Charcoal and Plant Growth Regulators on the Subculture of Seedlings}

To evaluate the effect of AC on the subculture of seedlings, seedlings with 1-2 leaves obtained from the protocorm differentiation stage were transferred to a $1 / 2 \mathrm{MS}$ medium supplemented with $1.0 \mathrm{mg} \cdot \mathrm{L}^{-1} \mathrm{Kin} ; 100 \mathrm{~mL} \cdot \mathrm{L}^{-1} \mathrm{CW}$; and $\mathrm{AC}$ at $0.5,1.0$ and $1.5 \mathrm{~g} \cdot \mathrm{L}^{-1}$. Based on the effect of AC on the subculture of seedlings, the 1/2 MS media supplemented with $1.0 \mathrm{~g} \cdot \mathrm{L}^{-1} \mathrm{AC}$ and $100 \mathrm{~mL} \cdot \mathrm{L}^{-1} \mathrm{CW}$ were selected to further determine the effect of PGRs on the subculture of seedlings. According to the results of preliminary experiments, several better PGR combinations $\left(0.2 \mathrm{mg} \cdot \mathrm{L}^{-1} \mathrm{BA}+0.5 \mathrm{mg} \cdot \mathrm{L}^{-1} \mathrm{NAA}\right.$, $0.5 \mathrm{mg} \cdot \mathrm{L}^{-1} \mathrm{BA}+0.5 \mathrm{mg} \cdot \mathrm{L}^{-1} \mathrm{Kin}, 1.0 \mathrm{mg} \cdot \mathrm{L}^{-1} \mathrm{Kin}$ ) were selected. Each experiment consisted of 3-4 independent replicates with 30 seedlings per replicate. Survival rate, rooting rate and average number of leaves were counted after culturing for 120 days. The culture conditions were the same as those at the protocorm differentiation stage.

\subsection{Effect of Plant Growth Regulators and Dolomite Flour on Seedling Growth and Rooting}

Seedlings that had 2-3 leaves at the subculture stage were transferred to a $1 / 2$ MS medium supplemented with $1.0 \mathrm{~g} \cdot \mathrm{L}^{-1} \mathrm{AC} ; 15 \mathrm{~g} \cdot \mathrm{L}^{-1}$ potato homogenate; $30 \mathrm{~g} \cdot \mathrm{L}^{-1}$ banana homogenate; and dolomite flour (Tai'an City Jia Ye Biotechnology Co., Ltd., Shandong, China) at $0.5,1.0$ and $2.0 \mathrm{~g} \cdot \mathrm{L}^{-1}$ or BA at $1.0,2.0,3.0$ and $4.0 \mathrm{mg} \cdot \mathrm{L}^{-1}$ in combination with NAA at $0.1,0.2,0.3$ and $0.4 \mathrm{mg} \cdot \mathrm{L}^{-1}$. Each treatment consisted of 40 seedlings. After 120 days, the surviving number of seedlings and the number of leaves and roots, maximum length of leaf and root and the height of shoots were calculated. The culture conditions were the same as those at the protocorm differentiation stage.

\subsection{Data Analysis}

The means of each parameter were compared using one-way analysis of variance (ANOVA), followed by Duncan's multiple range test (DMRT) at $p<0.05$. Statistical analysis was performed using SPSS statistics software version 20.0 (IBM Corporation, Armonk, NY, USA). Figures were made in Origin 2018 (OriginLab Corporation, Northampton, UK) and Adobe Photoshop 14.0 (Adobe Systems Inc., San Jose, CA, USA).

\section{Results}

\subsection{Seed Germination}

On average, P. tigrinum germinated in 19 days (Figure 1c), whereas P. appletoniantum germinated in 30 days. Maximum germination rates for $P$. tigrinum and P. appletoniantum were achieved in 7 and 9 weeks, respectively. Total seed germination rates of P. tigrinum grown on various media were not significantly different, but the browning rate and effective germination rate differed (Table 1). In fact, the main difference between $P$. tigrinum and $P$. appletoniantum was that the browning rate of $P$. tigrinum was much higher than that of $P$. 
appletoniantum, which was no greater than $2.85 \pm 0.35 \%$. This higher browning rate in $P$. tigrinum reduced effective seed germination.

Table 1. Effect of basal medium on seed germination of Paphiopedilum tigrinum and P. appletoniantum.

\begin{tabular}{cccccc}
\hline Species & Basal Media & Time Taken (days) & $\begin{array}{c}\text { Total Seed } \\
\text { Germination Rate (\%) }\end{array}$ & Browning Rate (\%) & $\begin{array}{c}\text { Effective Seed } \\
\text { Germination (\%) }\end{array}$ \\
\hline P. tigrinum & mHa & 19 & $87.87 \pm 0.63 \mathrm{a}$ & $12.48 \pm 7.26 \mathrm{~b}$ & $76.75 \pm 5.82 \mathrm{a}$ \\
& $1 / 4 \mathrm{MS}$ & 19 & $90.17 \pm 0.66 \mathrm{a}$ & $77.24 \pm 3.84 \mathrm{a}$ & $20.55 \pm 3.62 \mathrm{~b}$ \\
& $1 / 2 \mathrm{MS}$ & 19 & $88.99 \pm 2.59 \mathrm{a}$ & $77.27 \pm 0.26 \mathrm{a}$ & $20.23 \pm 0.82 \mathrm{~b}$ \\
\hline P. appletoniantum & $\mathrm{mHa}$ & 30 & $60.55 \pm 11.76 \mathrm{a}$ & $1.75 \pm 1.75 \mathrm{a}$ & $59.27 \pm 5.56 \mathrm{a}$ \\
& $1 / 4 \mathrm{MS}$ & 30 & $72.94 \pm 3.28 \mathrm{a}$ & $2.06 \pm 1.04 \mathrm{a}$ & $71.44 \pm 1.93 \mathrm{a}$ \\
& $1 / 2 \mathrm{MS}$ & 30 & $57.71 \pm 11.62 \mathrm{a}$ & $2.85 \pm 0.35 \mathrm{a}$ & $56.06 \pm 6.48 \mathrm{a}$ \\
\hline
\end{tabular}

The basal medium was supplemented with $1.0 \mathrm{mg} \cdot \mathrm{L}^{-1} \mathrm{Kin}, 100 \mathrm{~mL} \cdot \mathrm{L}^{-1}$ coconut water and $0.5 \mathrm{~g} \cdot \mathrm{L}^{-1}$ activated charcoal. Data are means $\pm \mathrm{SE}(n=2-4)$. Values followed by different letters within a column are significantly different at $p<0.05$ according to Duncan's multiple range test (DMRT).

The most effective medium for $P$. tigrinum germination was the mHa medium. $P$. tigrinum grown on $\mathrm{mHa}$ medium had the lowest browning rate $(12.48 \pm 7.26 \%)$ and the highest effective germination rate $(76.75 \pm 5.82 \%)$, and the protocorms remained healthy (Figure 1d).

The browning rate tended to increase on mHa medium with higher concentrations $\left(0-2.0 \mathrm{mg} \cdot \mathrm{L}^{-1}\right)$ of AC (Table 2). When seeds were sown on mHa medium with $0.1 \mathrm{~g} \cdot \mathrm{L}^{-1} \mathrm{AC}$ or without $\mathrm{AC}$, the browning rate was significantly lower. The effective seed germination rate was the highest $(88.10 \%)$ on $\mathrm{mHa}$ medium containing $0.1 \mathrm{~g} \cdot \mathrm{L}^{-1} \mathrm{AC}$, although this was not significantly different from the control (without AC).

Table 2. Effect of activated charcoal and plant growth regulators on seed germination of Paphiopedilum tigrinum.

\begin{tabular}{|c|c|c|c|c|}
\hline PGRs (mg. $\mathrm{L}^{-1}$ ) & $\operatorname{AC}\left(g \cdot L^{-1}\right)$ & $\begin{array}{c}\text { Total Seed } \\
\text { Germination Rate (\%) }\end{array}$ & Browning Rate (\%) & $\begin{array}{c}\text { Effective Seed } \\
\text { Germination (\%) }\end{array}$ \\
\hline $1.0 \mathrm{Kin}$ & 0 & $82.51 \pm 3.94 \mathrm{ab}$ & $0 \mathrm{~d}$ & $82.51 \pm 3.93 \mathrm{ab}$ \\
\hline $1.0 \mathrm{Kin}$ & 0.1 & $88.89 \pm 3.18 \mathrm{ab}$ & $0.86 \pm 0.86 \mathrm{~d}$ & $88.10 \pm 2.38 \mathrm{a}$ \\
\hline $1.0 \mathrm{Kin}$ & 0.5 & $94.03 \pm 0.03 a$ & $24.68 \pm 7.56 c$ & $69.14 \pm 7.14 b$ \\
\hline $1.0 \mathrm{Kin}$ & 1.0 & $83.90 \pm 0.17 \mathrm{ab}$ & $55.07 \pm 3.33 b$ & $37.64 \pm 2.02 c$ \\
\hline $1.0 \mathrm{Kin}$ & 2.0 & $80.07 \pm 3.73 b$ & $82.02 \pm 2.02 a$ & $14.32 \pm 0.94 \mathrm{~d}$ \\
\hline 0 & 0 & $74.62 \pm 2.31 \mathrm{f}$ & $0 \mathrm{~b}$ & $74.62 \pm 2.31 \mathrm{ab}$ \\
\hline $0.5 \mathrm{NAA}$ & 0 & $91.85 \pm 2.27 \mathrm{ab}$ & $17.83 \pm 15.50 \mathrm{~b}$ & $75.12 \pm 12.38 \mathrm{ab}$ \\
\hline $1.0 \mathrm{NAA}$ & 0 & $99.26 \pm 0.74 a$ & $44.25 \pm 6.66 a$ & $55.29 \pm 6.20 \mathrm{~cd}$ \\
\hline 2.0 NAA & 0 & $85.21 \pm 4.08 \mathrm{bcd}$ & $45.26 \pm 1.26 \mathrm{a}$ & $46.70 \pm 3.30 \mathrm{~d}$ \\
\hline $0.5 \mathrm{BA}$ & 0 & $78.20 \pm 1.17 \mathrm{def}$ & $1.00 \pm 1.00 \mathrm{~b}$ & $77.40 \pm 0.38 \mathrm{ab}$ \\
\hline $1.0 \mathrm{BA}$ & 0 & $84.17 \pm 0.04$ bcde & $3.03 \pm 1.14 b$ & $81.62 \pm 0.92 \mathrm{ab}$ \\
\hline $2.0 \mathrm{BA}$ & 0 & $80.63 \pm 0.63 c d e f$ & $7.60 \pm 0.10 b$ & $74.50 \pm 0.50 \mathrm{ab}$ \\
\hline $0.5 \mathrm{Kin}$ & 0 & $89.22 \pm 2.82 b c$ & $2.16 \pm 0.31 b$ & $87.29 \pm 2.49 a$ \\
\hline $1.0 \mathrm{Kin}$ & 0 & $86.57 \pm 1.07 \mathrm{bcd}$ & $1.09 \pm 0.19 b$ & $85.82 \pm 0.89 \mathrm{ab}$ \\
\hline $2.0 \mathrm{Kin}$ & 0 & $75.55 \pm 5.93 \mathrm{ef}$ & $10.68 \pm 3.86 b$ & $67.71 \pm 8.22 \mathrm{bc}$ \\
\hline
\end{tabular}

The basal medium was $\mathrm{mHa}$ medium supplemented with $100 \mathrm{~mL} \cdot \mathrm{L}^{-1}$ coconut water. Data are means $\pm \mathrm{SE}(n=2-4)$. Values followed by different letters within a column are significantly different at $p<0.05$ according to DMRT.

Supplementing media with NAA, BA and Kin significantly promoted total seed germination at all concentrations $\left(0.5,1.0\right.$ and $\left.2.0 \mathrm{mg} \cdot \mathrm{L}^{-1}\right)$ (Table 2). Media supplemented with $0.5 \mathrm{mg} \cdot \mathrm{L}^{-1} \mathrm{Kin}$ had the highest effective seed germination rate $(87.29 \%)$, although not significantly different from the control (Table 2). Browning was observed readily when seeds were grown on media supplemented with NAA.

The seeds of $P$. tigrinum germinated in all media irrespective of photoperiod (Table 3). Dark culture had no significant effect on the total germination rate of $P$. tigrinum but significantly decreased the browning rate. Seeds not cultured in the dark had the highest browning rate $(43.67 \pm 3.16 \%)$. Seeds cultured in the dark for 90 days had the highest 
effective seed germination rate $(81.66 \pm 7.09 \%)$, which was significantly higher than for seeds not cultured in the dark; however, the effective seed germination rates of seeds cultured in the dark for 30 or 60 days were not significantly different from those of controls. Protocorms remained healthy under dark conditions.

Table 3. Effect of dark culture on seed germination of Paphiopedilum tigrinum.

\begin{tabular}{cccc}
\hline $\begin{array}{c}\text { Dark Culture Time } \\
\text { (days) }\end{array}$ & $\begin{array}{c}\text { Total Seed } \\
\text { Germination Rate (\%) }\end{array}$ & Browning Rate (\%) & $\begin{array}{c}\text { Effective Seed } \\
\text { Germination (\%) }\end{array}$ \\
\hline 0 & $84.96 \pm 0.91 \mathrm{a}$ & $43.67 \pm 3.16 \mathrm{a}$ & $47.88 \pm 3.20 \mathrm{~b}$ \\
30 & $76.99 \pm 0.95 \mathrm{a}$ & $16.97 \pm 1.90 \mathrm{~b}$ & $63.91 \pm 0.67 \mathrm{ab}$ \\
60 & $80.39 \pm 6.34 \mathrm{a}$ & $15.01 \pm 2.64 \mathrm{~b}$ & $68.16 \pm 3.27 \mathrm{ab}$ \\
90 & $88.28 \pm 2.97 \mathrm{a}$ & $7.66 \pm 4.92 \mathrm{~b}$ & $81.66 \pm 7.09 \mathrm{a}$ \\
\hline
\end{tabular}

The basal medium was mHa medium supplemented with $1.0 \mathrm{mg} \cdot \mathrm{L}^{-1} \mathrm{Kin}, 0.5 \mathrm{~g} \cdot \mathrm{L}^{-1}$ activated charcoal and $100 \mathrm{~mL} \cdot \mathrm{L}^{-1}$ coconut water. Data are means $\pm \mathrm{SE}(n=2-4)$. Values followed by different letters within a column are significantly different at $p<0.05$ according to DMRT.

\subsection{Protocorm Differentiation}

Salt concentrations of basal media affected the development of protocorms into seedlings (Table 4). The rates of protocorm differentiation for both $P$. tigrinum and $P$. appletoniantum were significantly higher on the 1/4 MS medium than on 1/2 MS or MS medum. However, P. tigrinum individuals rarely rooted on the media tested, whereas about $56 \%$ of the P. appletoniantum individuals rooted. Thus, one important factor restricting the development of $P$. tigrinum protocorms into seedlings appears to be difficulty rooting.

Table 4. Effect of basal medium on protocorm differentiation of Paphiopedilum tigrinum and P. appletoniantum.

\begin{tabular}{cccc}
\hline Species & Basal Medium & $\begin{array}{c}\text { Protocorm } \\
\text { Differentiation Rate (\%) }\end{array}$ & Rooting Rate (\%) \\
\hline P. tigrinum & $1 / 4 \mathrm{MS}$ & $70.6 \pm 2.47 \mathrm{a}$ & $0 \mathrm{a}$ \\
& $1 / 2 \mathrm{MS}$ & $33.41 \pm 3.58 \mathrm{~b}$ & $0 \mathrm{a}$ \\
& $\mathrm{MS}$ & $8.33 \pm 0.96 \mathrm{c}$ & $0 \mathrm{a}$ \\
\hline P. appletoniantum & $1 / 4 \mathrm{MS}$ & $78.89 \pm 5.56 \mathrm{a}$ & $56.67 \pm 1.92 \mathrm{a}$ \\
& $1 / 2 \mathrm{MS}$ & $51.67 \pm 5.18 \mathrm{~b}$ & $46.67 \pm 4.30 \mathrm{~b}$ \\
& MS & $14.44 \pm 5.88 \mathrm{c}$ & $10.00 \pm 5.09 \mathrm{~b}$ \\
\hline
\end{tabular}

The basal medium was $\mathrm{mHa}$ medium supplemented with $1.0 \mathrm{mg} \cdot \mathrm{L}^{-1} \mathrm{Kin}$ and $100 \mathrm{~mL} \cdot \mathrm{L}^{-1}$ coconut water. Data are means \pm SE $(n=3-5)$. Values followed by different letters within a column are significantly different at $p<0.05$ according to DMRT.

Combinations of BA and NAA did not significantly promote P. tigrinum protocorm differentiation (Table 5). Although the differentiation rate was higher on the $1 / 4 \mathrm{MS}$ medium containing $1.0 \mathrm{mg} \cdot \mathrm{L}^{-1} \mathrm{BA}(66.13 \pm 2.77 \%)$, it was not significantly different from PGR-free media $(60.02 \pm 8.88 \%)$. Except for one case $\left(2.0 \mathrm{mg} \cdot \mathrm{L}^{-1} \mathrm{BA}\right.$ and $\left.0.1 \mathrm{mg} \cdot \mathrm{L}^{-1} \mathrm{NAA}\right)$, media supplemented with NAA showed an inhibitory effect on protocorm differentiation, although some thin roots were observed. Thus, adding NAA to media at the protocorm differentiation stage is not recommended.

P. tigrinum showed a significantly higher protocorm differentiation rate and rooting rate $(60.83 \pm 4.38 \%$ and $34.17 \pm 4.38 \%$, respectively) on the $1 / 4$ MS medium supplemented with $1.0 \mathrm{mg} \cdot \mathrm{L}^{-1} \mathrm{Kin}, 100 \mathrm{~mL} \cdot \mathrm{L}^{-1} \mathrm{CW}$ and $0.3 \mathrm{~g} \cdot \mathrm{L}^{-1} \mathrm{AC}$ than when grown under other treatments (Figure 2). At the protocorm differentiation stage, the first and second leaves were observed to elongate (Figure 1e,f). Roots began to form but were thin and short (Figure $1 \mathrm{~g}$ ). Few roots were observed on the AC-free medium, and the seedlings were poorly developed. 
Table 5. Effect of plant growth regulators on protocorm differentiation of Paphiopedilum tigrinum.

\begin{tabular}{|c|c|c|c|c|}
\hline $\begin{array}{c}\text { BA } \\
\left(\mathrm{mg} \cdot \mathrm{L}^{-1}\right)\end{array}$ & $\begin{array}{c}\text { Kin } \\
\left(\mathrm{mg} \cdot \mathrm{L}^{-1}\right)\end{array}$ & $\begin{array}{c}\text { NAA } \\
\left(\mathrm{mg} \cdot \mathrm{L}^{-1}\right)\end{array}$ & $\begin{array}{c}\text { Protocorm } \\
\text { Differentiation Rate (\%) }\end{array}$ & Rooting Rate (\%) \\
\hline 0 & 0 & 0 & $60.02 \pm 8.88 \mathrm{a}$ & $0 \mathrm{~b}$ \\
\hline 0.5 & 0.5 & 0 & $58.32 \pm 3.49 a$ & $0 \mathrm{~b}$ \\
\hline 0 & 1.0 & 0 & $61.67 \pm 2.89 a$ & $0 \mathrm{~b}$ \\
\hline 1.0 & 0 & 0 & $66.13 \pm 2.77 a$ & $0 \mathrm{~b}$ \\
\hline 1.0 & 0 & 0.1 & $39.17 \pm 2.85 b$ & $0 b$ \\
\hline 1.0 & 0 & 0.2 & $40.00 \pm 5.93 b$ & $2.50 \pm 1.60 \mathrm{~b}$ \\
\hline 1.0 & 0 & 0.5 & $24.44 \pm 1.11 b$ & $10.00 \pm 1.92 \mathrm{a}$ \\
\hline 2.0 & 0 & 0.1 & $62.85 \pm 3.52 \mathrm{a}$ & $\mathrm{Ob}$ \\
\hline 2.0 & 0 & 0.2 & $40.00 \pm 11.55 b$ & $2.22 \pm 2.22 b$ \\
\hline 2.0 & 0 & 0.5 & $26.67 \pm 8.82 b$ & $3.33 \pm 1.92 b$ \\
\hline
\end{tabular}

The basal medium was $1 / 4 \mathrm{MS}$ medium supplemented with $100 \mathrm{~mL} \cdot \mathrm{L}^{-1}$ coconut water. Data are means $\pm \mathrm{SE}$ $(n=3-5)$. Each treatment consisted of 3-5 independent replicates with 30 protocorms per replicate. Values followed by different letters within a column are significantly different at $p<0.05$ according to DMRT.

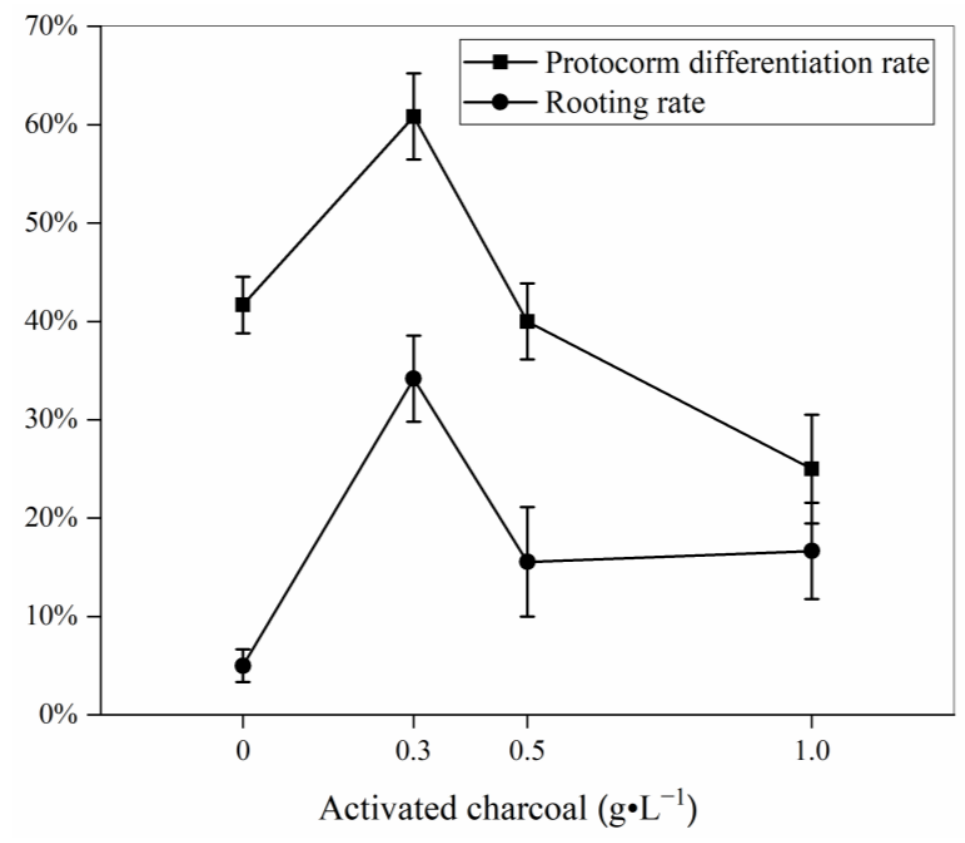

Figure 2. Effect of activated charcoal on protocorm differentiation of Paphiopedilum tigrinum. The basal medium was $1 / 4 \mathrm{MS}$ medium supplemented with $1.0 \mathrm{mg} \cdot \mathrm{L}^{-1} \mathrm{Kin}$ and $100 \mathrm{~mL} \cdot \mathrm{L}^{-1}$ coconut water. Each treatment consisted of 3-5 independent replicates with 30 protocorms per replicate. Data are means \pm SE $(n=3-5)$. Different letters represent significant difference at $p<0.05$ according to DMRT.

\subsection{Seedling Subculture}

At the seedling subculture stage, AC significantly promoted the growth of roots and leaves (Table 6), without significant differences between treatment concentrations $(0.5,1.0$ and $\left.1.5 \mathrm{~g} \cdot \mathrm{L}^{-1}\right)$. In $P$. tigrinum, the survival rate, rooting rate and number of leaves/shoots were significantly lower when grown without AC.

Preliminary experiments identified three combinations of BA, Kin and NAA for further experiments. In these experiments, the survival rate of seedlings, rooting rate and leaf number per individual were highest on media without PGRs (Table 7). The roots produced at this stage were short and thin. 
Table 6. Effect of activated charcoal on root and leaf growth of Paphiopedilum tigrinum.

\begin{tabular}{cccc}
\hline Activated Charcoal $\left(\mathbf{g} \cdot \mathbf{L}^{-\mathbf{1}}\right)$ & Survival Rate (\%) & Rooting Rate (\%) & Leaf Number \\
\hline 0 & $53.75 \pm 8.85 \mathrm{~b}$ & $15.00 \pm 2.67 \mathrm{~b}$ & $2.01 \pm 0.14 \mathrm{~b}$ \\
0.5 & $75.00 \pm 3.78 \mathrm{a}$ & $66.25 \pm 4.60 \mathrm{a}$ & $2.72 \pm 0.11 \mathrm{a}$ \\
1.0 & $72.22 \pm 4.34 \mathrm{a}$ & $66.67 \pm 4.41 \mathrm{a}$ & $2.52 \pm 0.12 \mathrm{a}$ \\
1.5 & $77.50 \pm 4.53 \mathrm{a}$ & $61.25 \pm 1.25 \mathrm{a}$ & $2.58 \pm 0.09 \mathrm{a}$ \\
\hline
\end{tabular}

The basal medium was $1 / 2$ MS medium supplemented with $1.0 \mathrm{mg} \cdot \mathrm{L}^{-1} \mathrm{Kin}$ and $100 \mathrm{~mL} \cdot \mathrm{L}^{-1}$ coconut water. Each treatment consisted of 3 independent replicates and each replicate consisted of 30 seedlings. Data are means $\pm \mathrm{SE}$ $(n=10)$. Values followed by different letters within a column are significantly different at $p<0.05$ according to DMRT.

Table 7. Effect of plant growth regulators on root and leaf growth of Paphiopedilum tigrinum.

\begin{tabular}{|c|c|c|c|c|c|}
\hline $\begin{array}{c}\text { BA } \\
\left(\mathrm{mg} \cdot \mathrm{L}^{-1}\right)\end{array}$ & $\begin{array}{c}\text { Kin } \\
\left(\mathrm{mg} \cdot \mathrm{L}^{-1}\right)\end{array}$ & $\begin{array}{c}\text { NAA } \\
\left(\mathrm{mg} \cdot \mathrm{L}^{-1}\right)\end{array}$ & $\begin{array}{c}\text { Survival Rate } \\
(\%)\end{array}$ & $\begin{array}{c}\text { Rooting Rate } \\
(\%)\end{array}$ & Leaf Number \\
\hline 0.2 & 0 & 0.5 & $77.50 \pm 6.20 \mathrm{ab}$ & $72.50 \pm 6.48 a$ & $2.59 \pm 0.17 b$ \\
\hline 0.5 & 0.5 & 0 & $65.71 \pm 4.81 b$ & $60.00 \pm 4.36 a$ & $2.87 \pm 0.10 \mathrm{ab}$ \\
\hline 0 & 1.0 & 0 & $72.22 \pm 4.34 \mathrm{ab}$ & $66.67 \pm 4.41 \mathrm{a}$ & $2.52 \pm 0.12 b$ \\
\hline 0 & 0 & 0 & $89.00 \pm 6.23 a$ & $68.00 \pm 6.29 a$ & $2.97 \pm 0.08 \mathrm{a}$ \\
\hline
\end{tabular}

The basal medium was $1 / 2 \mathrm{MS}$ medium supplemented with $100 \mathrm{~mL} \cdot \mathrm{L}^{-1}$ coconut water and $1.0 \mathrm{~g} \cdot \mathrm{L}^{-1}$ activated charcoal. Data are means $\pm \mathrm{SE}(n=10)$. Each treatment consisted of 3 independent replicates and each replicate consisted of 30 seedlings. Values followed by different letters within a column are significantly different at $p<0.05$ according to DMRT.

\subsection{Seedling Growth In Vitro}

The seedling survival rate was significantly affected by different combinations of BA and NAA (Table 8). As the concentrations of BA and NAA increased, the survival rate of $P$. tigrinum seedlings decreased. P. tigrinum seedlings grown on 1/2 MS medium containing BA and NAA had thicker roots; however, these seedlings had significantly lower survival rates, maximum leaf lengths, maximum root lengths and plant heights than those grown without PGRs. In contrast, media supplemented with dolomite flour significantly promoted the leaf number, leaf length and plant height of P. tigrinum. The most suitable concentration of dolomite flour was $0.5 \mathrm{~g} \cdot \mathrm{L}^{-1}$, which yielded seedlings with 4-5 leaves and 5-7 roots on the 1/2 MS medium (Figure 1h, i).

Table 8. Effect of plant growth regulators and dolomite flour on the seedling growth of Paphiopedilum tigrinum.

\begin{tabular}{|c|c|c|c|c|c|c|c|c|}
\hline $\begin{array}{c}\text { BA } \\
\left(\mathrm{mg} \cdot \mathrm{L}^{-1}\right)\end{array}$ & $\begin{array}{c}\text { NAA } \\
\left(\mathrm{mg} \cdot \mathrm{L}^{-1}\right)\end{array}$ & $\begin{array}{c}\text { Dolomite } \\
\text { Flour }\left(g \cdot L^{-1}\right)\end{array}$ & $\begin{array}{l}\text { Survival } \\
\text { Rate (\%) }\end{array}$ & $\begin{array}{c}\text { Leaf } \\
\text { Number }\end{array}$ & $\begin{array}{l}\text { Maximum Leaf } \\
\text { Length }(\mathrm{cm})\end{array}$ & Root Number & $\begin{array}{l}\text { Maximum Root } \\
\text { Length }(\mathrm{cm})\end{array}$ & $\begin{array}{c}\text { Shoot } \\
\text { Height }(\mathrm{cm})\end{array}$ \\
\hline 0 & 0 & 0 & 100.00 & $4.13 \pm 0.23 b c$ & $2.15 \pm 0.07 b$ & $7.48 \pm 0.38 \mathrm{a}$ & $1.74 \pm 0.10 \mathrm{a}$ & $3.15 \pm 0.11 b c$ \\
\hline 1.0 & 0.1 & 0 & 87.50 & $4.12 \pm 0.27 b c$ & $1.42 \pm 0.09 \mathrm{~d}$ & $6.97 \pm 0.37 \mathrm{a}$ & $1.23 \pm 0.09 b c$ & $2.39 \pm 0.12 \mathrm{~d}$ \\
\hline 2.0 & 0.2 & 0 & 73.33 & $5.18 \pm 0.41 \mathrm{a}$ & $1.79 \pm 0.14 \mathrm{c}$ & $6.59 \pm 0.52 \mathrm{ab}$ & $1.07 \pm 0.10 \mathrm{~cd}$ & $2.70 \pm 0.16 \mathrm{~cd}$ \\
\hline 3.0 & 0.3 & 0 & 26.67 & $3.22 \pm 0.52 c$ & $1.22 \pm 0.19 \mathrm{~d}$ & $4.00 \pm 0.82 \mathrm{~d}$ & $0.70 \pm 0.17 \mathrm{~d}$ & $1.80 \pm 0.27 \mathrm{e}$ \\
\hline 4.0 & 0.4 & 0 & 0 & - & - & - & - & - \\
\hline 0 & 0 & 0.5 & 100.00 & $5.20 \pm 0.29 a$ & $2.77 \pm 0.08 a$ & $6.15 \pm 0.42 \mathrm{abc}$ & $1.87 \pm 0.12 \mathrm{a}$ & $3.91 \pm 0.10 \mathrm{a}$ \\
\hline 0 & 0 & 1.0 & 100.00 & $5.03 \pm 26 a b$ & $2.76 \pm 0.13 a$ & $5.28 \pm 0.44 b c d$ & $1.99 \pm 0.19 \mathrm{a}$ & $3.94 \pm 0.19 a$ \\
\hline 0 & 0 & 2.0 & 100.00 & $4.73 \pm 0.26 \mathrm{ab}$ & $2.44 \pm 0.09 \mathrm{ab}$ & $4.73 \pm 0.33 c d$ & $1.65 \pm 0.14 \mathrm{ab}$ & $3.61 \pm 0.13 \mathrm{ab}$ \\
\hline
\end{tabular}

The basal medium was 1/2 MS medium supplemented with $1.0 \mathrm{~g} \cdot \mathrm{L}-1$ activated charcoal, $15 \mathrm{~g} \cdot \mathrm{L}-1$ potato homogenate and $30 \mathrm{~g} \cdot \mathrm{L}-1 \mathrm{banana}$ homogenate. Each treatment consists of 4 bottles, and each bottle consists of 10 seedlings. Data are means \pm SE $(n=8-40)$. Values followed by different letters within a column are significantly different at $p<0.05$ according to DMRT.

\section{Discussion}

\subsection{Effect of Basal Medium on Seed Germination, Protocorm Differentiation and Seedling Growth}

Basal media play a crucial role in seed germination and protocorm development of Paphiopedilum species $[12,22,26]$. In the present study, the germination rate of P. tigrinum was significantly higher on mHa media than on $1 / 2 \mathrm{MS}$ or $1 / 4 \mathrm{MS}$ medium, mostly because seeds cultured on 1/2 MS and 1/4 MS media underwent serious browning. This increase in germination rate might be related to the macroelement content in mHa medium. Calcium, which is an essential element for plant growth and plays a prominent role in 
cell mitosis, is present at higher levels in $\mathrm{mHa}\left(500 \mathrm{mg} \cdot \mathrm{L}^{-1}\right)$ medium than in $1 / 2 \mathrm{MS}$ $\left(220 \mathrm{mg} \cdot \mathrm{L}^{-1}\right)$ and $1 / 4 \mathrm{MS}\left(110 \mathrm{mg} \cdot \mathrm{L}^{-1}\right)$ media. In P. delenatii, calcium-deficient media have been shown to lead to protocorm death [27]. In addition, phosphate has been shown to play a decisive role in the induction and development of protocorm-like bodies and callus of Cymbidium hybrids [28]. Similarly, phosphate-rich VW medium has been linked to higher seed germination rates and larger protocorms in various Paphiopedilum species [15,22]. Thus, the higher rate of effective seed germination we observed in P. tigrinum grown on mHa medium can be partially explained by higher phosphate concentrations.

Protocorm growth and differentiation of $P$. tigrinum and P. appletoniantum were superior when grown in media with a lower salt concentration (1/4 MS medium). This finding is consistent with previous work that showed $P$. Maudiae germination is greater in $1 / 2 \mathrm{MS}$ media than in 3/4 MS or MS medium and that seeds browned and shoot buds did not form in high-salt media [29]. Nhut et al. also suggested that nutrition-poor Knudson C medium is suitable for germination of $P$. delenatii seed [8]. High salt concentrations in the medium may damage cells. Our results show that $P$. tigrinum was intolerant of high salt concentrations at both the seed germination and protocorm differentiation stages. However, extremely low salt concentrations may inhibit seed germination and protocorm development due to insufficient nutrients. For example, the seed germination rate of $P$. concolor has been found to be significantly lower on $1 / 8 \mathrm{MS}$ medium than on $1 / 2 \mathrm{MS}$ or $1 / 4 \mathrm{MS}$ medium [30]. In fact, seed germination in $P$. wardii has been shown to be significantly affected by not only salt concentration but also concentrations of various elements [15].

\subsection{Effect of Activated Charcoal on Seed Germination, Protocorm Differentiation and Seedling Development}

The addition of AC to basal media can influence orchid seed germination, rooting, rhizome growth and plant development [31-35]. However, optimal AC concentrations in Paphiopedilum are species- and stage-specific.

Browning occurs frequently in tissue culture. It is caused by the activation of polyphenol oxidase in tissues, which changes the metabolism of cells. Phenolic substances are oxidized to produce quinones, which are brown in color and will gradually spread into the culture medium, thereby inhibiting the activity of other enzymes and poisoning the culture materials [36]. AC can adsorb phenols and inactivate polyphenol oxidase and peroxidase, thus inhibiting the browning of explant [16,37], but has no effects on species that have no obvious browning in the culture medium [38]. Li et al. reported that protocorm browning and death in $P$. concolor are inhibited by adding $1 \mathrm{~g} \cdot \mathrm{L}^{-1} \mathrm{AC}$, while the browning and mortality rates increase when the concentration is $2 \mathrm{~g} \cdot \mathrm{L}^{-1} \mathrm{AC}$ [30]. In the present study, reducing the $\mathrm{AC}$ concentration to $0.1 \mathrm{~g} \cdot \mathrm{L}^{-1} \mathrm{AC}$ effectively reduced protocorm browning. Similarly, in Calanthe hybrids, supplementing media with relatively low concentrations of AC $\left(0.1 \mathrm{~g} \cdot \mathrm{L}^{-1}\right)$ inhibits browning and accelerates seed germination [39]. On the contrary, relatively high concentrations of AC $\left(2.0 \mathrm{~g} \cdot \mathrm{L}^{-1}\right)$ promote seed germination in P. spicerianum $[40,41]$. We speculate that $P$. tigrinum is highly sensitive to AC concentration at the early stages of seedling development. Excessive AC can absorb some substances in the medium that are used for seed germination and protocorm development, release some substances that can inhibit seed germination or otherwise induce protocorm browning [37].

The highest rate of protocorm differentiation in P. tigrinum was observed on the $1 / 4 \mathrm{MS}$ medium containing $0.3 \mathrm{~g} \cdot \mathrm{L}^{-1} \mathrm{AC}$ at the protocorm differentiation stage. However, excessive AC increased the extent of protocorm browning and drastically slowed the development of the remaining protocorms, which is consistent with previous findings [18]. In addition, the medium (without $\mathrm{AC}$ ) of $P$. tigrinum turned brown, while there was no discoloration of the medium of P. appletoniantum, which implies that some phenolic substances were produced in the medium cultured with seeds of P. tigrinum and AC can absorb those substances so as to promote protocorm differentiation and seedling growth. However, the mechanism of how AC promotes or inhibits plant growth remains unclear. Johansson et al. demonstrated that many substances in the medium were released in large quantities from AC [38]. However, the addition of AC water extracts to the medium has no 
effects on orchid seedling growth [42]. In addition, AC may have synergistic effects with other substances such as organic additives and hormones, which need further experimental design to verify.

At the protocorm differentiation stage, roots were hardly observed in P. tigrinum, while about $56 \%$ of P. appletoniantum individuals formed roots, which may be related to differences in genotype, physio-ecological characteristics and nutrient requirements [21]. At the rooting stage, we observed that $1.5 \mathrm{~g} \cdot \mathrm{L}^{-1} \mathrm{AC}$ significantly promoted the growth of roots and leaves of $P$. tigrinum. This finding is consistent with previous research that high-level AC $\left(0.6 \mathrm{~g} \cdot \mathrm{L}^{-1}\right)$ increased the number and the length of roots [43]. Our finding indicates that high-level $\mathrm{AC}$ is not conducive to seed germination and protocorm development in P. tigrinum but is useful for induction of roots. A previous study also indicates that AC inhibits the seed germination but promotes the development of seedlings of P. ciliolare [18]. Thus, AC requirements vary across developmental stages.

\subsection{Effect of Plant Growth Regulators on Seed Germination, Protocorm Differentiation and Seedling Development}

Orchid seed germination, protocorm development and seedling growth are affected by PGRs, but the requirements for exogenous PGRs vary greatly among species [44-46]. Here, plant growth regulators (NAA, Kin or BA at $0.5-2.0 \mathrm{mg} \cdot \mathrm{L}^{-1}$ ) did not significantly promote P. tigrinum seed germination. In fact, higher concentrations of PGRs caused protocorm browning and even death in P. tigrinum. This response to PGRs is similar to that of P. primulinum 'Jinzhoubaochun' [47]. Thus, PGRs do not appear to be required for seed germination and protocorm differentiation in Paphiopedilum species.

Protocorm proliferation can be induced by the combined use of auxin and cytokinin, thereby promoting seedling growth and development. Generally, auxin promotes root formation, whereas cytokinin promotes bud development and cell division [25]. Previous studies on P. emersonii have shown that combinations of BA and NAA (20:1) promote protocorm proliferation [48]. However, in our study, P. tigrinum did not proliferate on 1/4 MS media containing different combinations of BA and NAA at the protocorm differentiation stage. Moreover, seedling growth was inhibited on $1 / 4$ MS media containing PGRs. This finding is consistent with previous studies reporting that the addition of 2,4-D and NAA to $1 / 2$ MS medium inhibits seedling growth [17]. It is possible that this inhibition of seedling growth is caused by genotype differences. Alternatively, this inhibition may indicate that the PGRs and concentrations in our study are unsuitable for P. tigrinum proliferation and growth, especially NAA. NAA greatly promoted germination and accelerated early-stage development but was toxic to protocorms. In species that can tolerate high NAA concentrations, such as P. hirsutissimum and P. spicerianum, biomass, leaf width, rooting rate and seedling growth are increased $[41,49]$. Our finding that exogenous PGRs are not conducive to $P$. tigrinum growth suggests that these plants contain adequate endogenous PGRs [50]. Moreover, our finding that $P$. tigrinum hardly proliferated at the protocorm differentiation stage but did proliferate in the form of tillers during the seedling subculture and rooting stages indicates that investigating how to make this species proliferate more efficiently is worthy of further study.

\subsection{Effect of Dark Treatment on Seed Germination}

In our study, more P. tigrinum seeds germinated when cultured in the dark than in the light. Although this finding is at odds with results from several orchid genera [51], it is consistent with results observed in other Paphiopedilum species (P. wardii and P. spicerianum) $[15,41]$. This emphasizes that the light requirements for orchid seed germination are species-specific [12]. In addition, we found that when P. tigrinum seeds were cultured under dark conditions for 30,60 or 90 days, the browning rates were significantly lower. This finding is similar to previous work that showed most protocorms of $P$. sukhakulii turn brown in continuous light and die off at an early stage of development [52]. Taken together, these results suggest that dark treatment is an effective method of preventing protocorm browning in P. tigrinum and possibly other Paphiopedilum species. One plausible 
explanation for this phenomenon is that the darkness mimics underground environments of orchid habitats [43]. However, light is necessary for protocorms to turn green to form seedlings [15].

\subsection{Effect of Dolomite Flour on Seedling Growth In Vitro}

Dolomite is a weak alkaline mineral mainly composed of calcium carbonate and magnesium carbonate [53]. It is generally used as a modifier of soil $\mathrm{pH}$ in the field, although rarely used in plant micropropagation. Belyakova and Ivannikov found that calcium pantothenate, sulfuric acid and dolomite flour can significantly promote the growth of leaves in P. delenatii [27]. Similarly, we found that adding dolomite flour to medium promotes seedling growth in P. tigrinum, which grows on rocks or rocky places in the wild. Dolomite flour may significantly promote seedling growth in P. tigrinum by providing a certain amount of calcium and magnesium, which creates growth conditions similar to the species' natural habitat.

\section{Conclusions}

The present study investigated the effects of basal media, plant growth regulators, dark culture, AC and dolomite flour on P. tigrinum seed germination and seedling differentiation. We found that the major obstacles to propagating $P$. tigrinum seedlings by asymbiotic germination include protocorm browning at the seed germination stage and the absence of protocorm rooting at the protocorm differentiation stage. We successfully established an effective protocol for seed germination, protocorm differentiation and seedling development of $P$. tigrinum by optimizing the basal medium and culture conditions. These results are of great significance for the utilization and conservation of P. tigrinum germplasm resources.

Author Contributions: Conceptualization, S.Z. and J.H.; methodology, L.Y. and J.H.; software, L.Y.; validation, S.Z., J.H. and L.Y.; formal analysis, L.Y.; investigation, J.H.; resources, S.Z. and J.H.; data curation, L.Y.; writing —original draft preparation, L.Y.; writing-review and editing, S.Z. and J.H.; visualization, L.Y.; supervision, S.Z. and J.H.; project administration, S.Z.; funding acquisition, S.Z. All authors have read and agreed to the published version of the manuscript.

Funding: This work is financially supported by the National Natural Science Foundation of China (31970361), the Applied Basic Research Plan of Yunnan Province (2018FA016), the project for Construction of International Flower Technology Innovation Center and Achievement Industrialization (2019ZG006), the Project for Innovation Team of Yunnan Province (202105AE160012) and the project from the Germplasm Bank of Wild Species.

Institutional Review Board Statement: Not applicable.

Informed Consent Statement: Not applicable.

Conflicts of Interest: The authors declare no conflict of interest.

\section{References}

1. Cribb, P. The Genus Paphiopedilum, 2nd ed.; Natural History Publications: Borneo, Indonesia, 1998.

2. Averyanov, L.; Cribb, P.; Loc, P.K.; Hiep, N.T. Slipper Orchids of Vietnam; Kew, Royal Botanic Gardens, Compass Press: Richmond, UK, 2003.

3. Lee, Y.I.; Yeung, E.C.; Lee, N.; Chung, M.C. Embryo development in the lady's slipper orchid, Paphiopedilum delenatii, with emphasis on the ultrastructure of the suspensor. Ann. Bot. 2006, 98, 1311-1319. [CrossRef] [PubMed]

4. $\quad$ Liu, Z.J.; Chen, X.Q.; Chen, L.J.; Lei, S.P. The genus Paphiopedilum in China; Science Press: Beijing, China, 2009 ; pp. 68-72.

5. Rankou, H.; Averyanov, L. Paphiopedilum tigrinum. In The IUCN Red List of Threatened Species 2015: e.T46699A3011579; International Union for Conservation of Nature and Natural Resources: Gland, Switzerland, 2015. [CrossRef]

6. CITES. Convention on International Trade in Endangered Species of Wild Fauna and Flora, Appendices I, II and III. 2012. Available online: http:/ / www.cites.org (accessed on 22 June 2021).

7. Luan, V.Q.; Huy, N.P.; Nam, N.B.; Huong, T.T.; Hien, V.T.; Nien, N.T.T.; Hai, N.T.; Thinh, D.K.; Nhut, D.T. Ex vitro and in vitro Paphiopedilum delenatii Guillaumin stem elongation under light-emitting diodes and shoot regeneration via stem node culture. Acta Physiol. Plant. 2015, 37, 136. [CrossRef]

8. Nhut, D.T.; Trang, P.T.T.; Vu, N.H.; Thuy, D.T.T.; Van Khiem, D.; Van Binh, N.; Van, K.T.T. A wounding method and liquid culture in Paphiopedilum delenatii propagation. Propag. Ornam. Plants 2005, 5, 158-163. 
9. Ng, C.Y.; Saleh, N.M.; Zaman, F.Q. In vitro multiplication of the rare and endangered slipper orchid, Paphiopedilum rothschildianum (Orchidaceae). Afr. J. Biotechnol. 2010, 9, 2062-2068.

10. Ng, C.Y.; Saleh, N.M. In vitro propagation of Paphiopedilum orchid through formation of protocorm-like bodies. Plant Cell Tissue Organ Cult. 2011, 105, 193-202. [CrossRef]

11. Hong, P.I.; Chen, J.T.; Chang, W.C. Plant regeneration via protocorm-like body formation and shoot multiplication from seedderived callus of a maudiae type slipper orchid. Acta Physiol. Plant. 2008, 30, 755-759. [CrossRef]

12. Pierik, R.L.M.; Sprenkels, P.A.; Van, D.H.B.; Van, D.M.Q.S. Seed germination and further development of plantlets of Paphiopedilum ciliolare Pfitz. in vitro. Sci. Hortic. 1988, 34, 139-153. [CrossRef]

13. Zhang, S.B.; Yang, Y.J.; Li, J.W.; Qin, J.; Zhang, W.; Huang, W.; Hu, H. Physiological diversity of orchids. Plant Divers. 2018, 40, 196-208. [CrossRef] [PubMed]

14. Knudson, L. Non-symbiotic germination of orchid seeds. Bot. Gaz. 1922, 73, 1-25. [CrossRef]

15. Zeng, S.J.; Wu, K.L.; Teixeira da Silva, J.A.; Zhang, J.X.; Chen, Z.L.; Xia, N.H.; Duan, J. Asymbiotic seed germination, seedling development and reintroduction of Paphiopedilum wardii Sumerh., an endangered terrestrial orchid. Sci. Hortic. 2012, 138, 198-209. [CrossRef]

16. Chen, Y.; Goodale, U.M.; Fan, X.L.; Gao, J.Y. Asymbiotic seed germination and in vitro seedling development of Paphiopedilum spicerianum: An orchid with an extremely small population in China. Glob. Ecol. Conserv. 2015, 3, 367-378. [CrossRef]

17. Diengdoh, R.V.; Kumaria, S.; Tandon, P.; Das, M.C. Asymbiotic germination and seed storage of Paphiopedilum insigne, an endangered lady's slipper orchid. S. Afr. J. Bot. 2017, 112, 215-224. [CrossRef]

18. Hossain, M.M.; Sharma, M.; Pathak, P. In vitro propagation of Dendrobium aphyllum (Orchidaceae)-seed germination to flowering. J. Plant Biochem. Biotechnol. 2013, 22, 157-167. [CrossRef]

19. Imsomboon, T.; Thammasiri, K.; Kosiyachinda, P. Effects of $\mathrm{pH}$ and sucrose on seed germination of Paphiopedilum exul (Ridl.) Rolfe. Acta Hortic. 2017, 1167, 95-100. [CrossRef]

20. Kumar, R.; Chakraborti, M.; Sailo, N.; Bhutia, T.C.; Singh, D.R. Asymbiotic seed germination and in vitro seedling development of Paphiopedilum villosum (Lindl.) Stein, a valuable and vulnerable lady's slipper orchid from India. Curr. Sci. 2018, 114, 266-269. [CrossRef]

21. Chen, T.Y.; Chen, J.T.; Chang, W.C. Plant regeneration through direct shoot bud formation from leaf cultures of Paphiopedilum orchids. Plant Cell Tissue Organ Cult. 2004, 76, 11-15. [CrossRef]

22. Long, B.; Niemiera, A.X.; Cheng, Z.Y.; Long, C.L. In vitro propagation of four threatened Paphiopedilum species (Orchidaceae). Plant Cell Tissue Organ Cult. 2010, 101, 151-162. [CrossRef]

23. Zeng, S.J.; Xia, N.H.; Chen, Z.L.; Wu, K.L.; Duan, J. Evaluation of ornamental value of Paphiopedilum distributed in China and analysis of utilization prospect in south-China. Chin. Wild Resour. 2011, 30, 9-13.

24. Harvais, G. An improved culture medium for growing the orchid Cypripedium reginae axenically. Can. J. Bot. 1982, 60, 2547-2555. [CrossRef]

25. Huang, J.L.; Hu, H. Seed germination requirements of Cypripedilum flavum in axenic culture. Acta Bot. Yunnanica 2001, 23, 105-108.

26. Zeng, S.J.; Wang, J.; Wu, K.L.; Teixeira da Silva, J.A.; Duan, J. In vitro propagation of Paphiopedilum hangianum Perner and Gruss. Sci. Hortic. 2013, 151, 147-156. [CrossRef]

27. Belyakova, I.; Ivannikov, R. Effect of calcium compounds on growth and development Paphiopedilum delenatii Guillaumin in vitro. In Proceedings of the X International Scientific and Practical Conference "Conservation and Cultivation of Orchids", Minsk, Belarus, 1-5 June 2015.

28. Teixeira da Silva, J.A.; Yam, T.W.; Fukai, S.; Nayak, N.R.; Tanaka, M. Establishment of optimum nutrient media for in vitro propagation of Cymbidium Sw. (Orchidaceae) using protocorm-like body segments. Propag. Ornam. Plants 2005, 5, $129-136$.

29. Chen, X.D.; Kang, H.T.; Zhou, J.M.; Zhang, T.; Lin, B.H.; Zhang, J.H. Study on asymbiotic germination and tissue culture of Paphiopedilum Maudiae. J. Minnan Norm. Univ. 2017, 3, 73-76.

30. Li, X.L.; Huang, C.Y.; Song, Q.; Zhou, J.Y.; Wang, X.G.; Qu, T.T.; Huang, F.L.; Bu, Z.Y. In vitro symbiotic germination and propagation of Paphiopedilum concolor (Lindl.) Pfitz. Plant Sci. J. 2016, 34, 127-134.

31. Choi, S.O.; Chung, J.D. Effects of media on multiplication of rhizomes and growth of seedlings through asymbiotic seed germination of oriental Cymbidium. Hortic. Environ. Biotechnol. 1989, 30, 294-302.

32. Kim, J.Y.; Lee, J.S. Effect of cultural conditions on rhizome growth and organogenesis of Cymbidium lancifolium native to Korea in vitro. J. Korean Soc. Hortic. Sci. 1992, 33, 471-476.

33. George, P.S.; Ravishankar, G.A. In vitro multiplication of Vanilla planifolia using axillary bud explants. Plant Cell Rep. 1997, 16, 490-494. [CrossRef]

34. Moraes, L.M.; Faria, R.T.; Cuquel, F.L. Activated charcoal for in vitro propagation of Brazilian orchids. Acta Hortic. 2005, 683, 383-390. [CrossRef]

35. Thompson, D.I.; Edwards, T.J.; Staden, J.V. Evaluating asymbiotic seed culture methods and establishing Disa (Orchidaceae) germinability in vitro: Relationships, requirements and first-time reports. Plant Growth Regul. 2006, 49, 269-284. [CrossRef]

36. Gao, G.X. Browning in plant tissue culture. Plant Physiol. Commun. 1999, 35, 501-506.

37. Pan, M.J.; Van Staden, J. The use of charcoal in in vitro culture-A review. Plant Growth Regul. 1998, 26, 155-163. [CrossRef]

38. Johansson, L.B.; Calleberg, E.; Gedin, A. Correlations between activated charcoal, Fe-EDTA and other organic media ingredients in cultured anthers of Anemone canadensis. Physiol. Plant. 1990, 80, 243-249. [CrossRef] 
39. Shin, Y.K.; Baque, M.A.; Lee, E.J.; Paek, K.Y. Effects of activated charcoal, hormones and ultrasonic pre-treatments on in vitro germination and protocorm formation of Calanthe hybrids. Aust. J. Crop. Sci. 2011, 5, 582-588.

40. Ding, C.C.; Yu, H.; Liu, F.Y. Factors affecting the germination of Paphiopedilum armeniacum. Acta Bot. Yunnanica 2004, $26,673-677$.

41. Kaur, S.; Bhutani, K.K. In vitro propagation of Paphiopedilum spicerianum (Reichb. F.) Pfitz. Floric. Ornam. Biotechnol. 2013, 7, 65-70.

42. Ernst, R. Studies in asymbiotic culture of orchids. Am. Orchid. Soc. 1975, 44, 12-18.

43. Yan, N.; Hu, H.; Huang, J.L.; Xu, K.; Wang, H.; Zhou, Z.K. Micropropagation of Cypripedium flavum through multiple shoots of seedlings derived from mature seeds. Plant Cell Tissue Organ Cult. 2006, 84, 114-118. [CrossRef]

44. Hossain, M.M. Asymbiotic seed germination and in vitro seedling development of Epidendrum ibaguense Kunth. (Orchidaceae). Afr. J. Biotechnol. 2008, 7, 3614-3619.

45. Roy, A.R.; Patel, R.S.; Patel, V.V.; Sajeev, S.; Deka, B.C. Asymbiotic seed germination, mass propagation and seedling development of Vanda coerulea Griff ex. Lindl. (Blue Vanda): An in vitro protocol for an endangered orchid. Sci. Hortic. 2011, 128, 325-331. [CrossRef]

46. Abraham, S.; Augustine, J.; Thomas, T.D. Asymbiotic seed germination and in vitro conservation of Coelogyne nervosa A. Rich. an endemic orchid to Western Ghats. Physiol. Mol. Biol. Plants 2012, 18, 245-251. [CrossRef]

47. Zhou, L.; Deng, K.Y.; Xu, Z.H. In vitro asymbiotic germination and propagation of Paphiopedilum primulinum 'Jinzhoubaochun'. Plant Physiol. J. 2013, 49, 1250-1254.

48. Tian, F.; Jiang, Y.L.; Luo, Z.Q.; Wang, L.H. Asymbiotic Germination and in vitro Seedling Cultivation of Paphiopedilum emersonii. Guizhou For. Sci. Technol. 2014, 42, 34-38.

49. Chen, B.L.; Chen, E.; Yang, S.T.; Wang, H.X.; Gong, J.Y.; Su, L.H. Effects of different medium components on in vitro culture of Paphiopedilum hirsutissimum. J. South. Agric. 2016, 47, 1730-1736.

50. Lo, S.F.; Nalawade, S.M.; Kuo, C.L.; Chen, C.L.; Tsay, H.S. Asymbiotic germination of immature seeds, plantlet development and ex vitro establishment of plants of Dendrobium tosaense Makino-A medicinally important orchid. Vitr. Cell. Dev. Biol.-Plant 2004, 40, 528-535. [CrossRef]

51. Arditti, J.; Michaud, J.D.; Oliva, A.P. Seed germination of North American orchids. I. native California and related species of Calypso, Epipactis, Goodyera, Piperia, and Platanthera. Bot. Gaz. 1981, 142, 442-453. [CrossRef]

52. Tay, L.J.; Takeno, K.; Hori, Y. Culture conditions suitable for in vitro seed-germination and development of seedlings in Paphiopedilum. J. Jpn. Hortic. Sci. 1988, 57, 243-249. [CrossRef]

53. Erofeev, V.; Kalashnikov, V.; Emelyanov, D.; Balathanova, E.; Erofeeva, I.; Smirnov, V.; Tretiakov, I.; Matvievskiy, A. Biological resistance of cement composites filled with dolomite powders. Mater. Sci. Forum 2016, 871, 33-39. [CrossRef] 